\title{
Diets of desert mule deer
}

\author{
PAUL R. KRAUSMAN, AMY J. KUENZI, RICHARD C. ETCHBERGER, KURT R. RAUTENSTRAUCH, \\ LEONARD L. ORDWAY, AND JOHN J. HERVERT
}

\begin{abstract}
Authors are professor, Wildlife and Fisheries Science Program, University of Arizona, Tucson, Ariz.; graduate research assistant, Wildlife and Fisheries Science Program, University of Arizona, Tucson, Ariz; assistant professor, Fisheries and Wildlife Department, Uintah Basin Branch Campus of Utah State University, Vernal, Ut.; research scientist, EEG consultants, Las Vegas, Nev.; field supervisor, Arizona Game and Fish Department, Mesa, Ariz,; and wildlife program manager, Arizona Game and Fish Department, Yuma, Ariz. At the time the research was conducted, Kuenzi, Etchberger, Rautenstrauch, Ordway, and Hervert, were graduate research assistants, Wildlife and Fisheries Program, University of Arizona, Tucson, Ariz
\end{abstract}

Abstract

We studied the diets of desert mule deer (Odocoileus hemionus crooki Mearns) at 3 sites in Arizona and collated this information with that of previous diet studies of desert mule deer across their range in the United States. We documented 96 browse, 69 forb, 14 succulent, and 6 grass species that each constituted $\geq 1 \%$ of the diet during $\geq 1$ season. The occurrence of individual plant species varied spatially and temporally. Changes in nutrient levels and climatic influence on relative availability and phenology of plant species likely influenced diet. Desert mule deer rely heavily on browse and forbes, which make up the majority of their diet $(>90 \%)$. Grasses and succulents were generally $<5 \%$ of the diet. Rangeland managers should strive to keep desert rangelands productive with a diversity of forage so animals have opportunities to exercise free choice of diet.

Key Words: Arizona, desert mule deer, diet, Odocoileus hemionus crooki

Desert mule deer (Odocoileus hemionus crooki Mearns) are endemic to desert shrub and chaparral areas of the southwestern United States and northern Mexico (Wallmo 1981). In the United States their range extends from south of the Gila River, Arizona eastward into central New Mexico and the Texas Panhandle (Hoffmeister 1962). The abundance and distribution of a species within its range is influenced by environmental components necessary for existence including food (Litvaitis et al. 1994). We reviewed the diet studies of desert mule deer that have been conducted; most were confined to small areas and few plant species were found in the diet when compared to the number of plant species eaten throughout their range.

The objectives of our study were to provide new information on desert mule deer diets obtained from 3 sites in Arizona and to collate this information with existing information to obtain a comprehensive list of plant species eaten by desert mule deer in

Research was funded by the United States Bureau of Reclamation under Contract 9-07-30-X069 and the Arizona Agricultural Experiment Station. Authors thank M. Murphy for carrying out the micro-histological analysis of fecal samples. J. Rohrer, B.D. Leopold, S.G. Torres, and T.L. Steel assisted with sampling. J.C. Tull and V.C. Bleich provided constructive reviews of earlier drafts of the manuscript. V. Catt and S. Klein prepared drafts of the manuscript.

Manuscript accepted 19 Oct. 1996
Resúmen

Estudiamos la dieta del venado bura del desierto (Odocoileus hemionus crooki Mearns) en tres sitios del estado de Arizona y cotejamos esta información con los estudios previos de dieta sobre esta especie, a lo largo de su rango de distribucion en los Estados Unidos. Nosotros registramos 96 plantas arbustivas, 69 especies de hierbas, 14 suculentas y 6 especies de pastos en donde cada una de estas categorías constituyó el $1 \%$ más de la dieta durante una o más de las estaciones. La presencia de estas especies de plantas varió espacial y temporalmente. Los cambios en los niveles de nutrientes así como la influencia climática sobre la disponibilidad relativa y fenología de las plantas, pudieron haber influenciado la composición de la dieta. El venado bura depende grandemente de arbustos y hierbas, los cuales constituyen una gran parte de su dieta ( $>90 \%$ ). Los pastos y suculentas constituyeron menos del $5 \%$ de la dieta. Los manejadores de pastizales de ambientes desérticos deben de esforzarse por mantener las áreas de forrajeo en forma productiva y con una diversidad tal de forraje, que permita a los animales tener una dieta de elección libre.

the United States. It is important to understand desert mule deer diets to enhance management practices.

\section{Materials and Methods}

We conducted diet studies in 3 areas of Arizona: King Valley, which lies within the boundaries of the Kofa National Wildlife Refuge, Yuma County; the Belmont Mountains, western Maricopa County; and the Picacho Mountains, Pinal County. Elevations in King Valley ranged from 1,000 to $1,500 \mathrm{~m}$. Elevations in the Belmont Mountains ranged from $415 \mathrm{~m}$ in the lowlands to $1,042 \mathrm{~m}$ at Sugarloaf Mountain. Elevations in the Picacho Mountains ranged from $485 \mathrm{~m}$ in the surrounding flats to $1,374 \mathrm{~m}$ at Newman Peak. Annual precipitation is similar in the Belmont and Picacho mountains, averaging 20 and $22 \mathrm{~cm}$, respectively, with much of the rain occurring during the July-September monsoon season and during winter (Sellers and Hill 1974). King Valley, on the northwest edge of desert mule deer range, is one of the hottest and driest regions inhabited by 
mule deer. The average annual precipitation is $11-17 \mathrm{~cm}$ (Sellers and Hill 1974).

The Belmont and Picacho mountain study areas are vegetated with plant species characteristic of Sonoran Desert scrub. Creosotebush (Larrea tridentata [D.C.]Coville) and triangle bursage (Ambrosia deltoidea Torr.) dominate large areas between dry washes. Dominant species within dry washes include blue palo verde (Cercidium floridum Benth.), ironwood (Olneya testota Gray), white brittle bush (Encelia farinosa Gray), wolfberry (Lycium spp.), and jojoba (Simmondsia chinensis [Link] Schneid). Most flora in the southern half of King Valley are restricted to washes. The uplands between washes are usually covered with desert pavement (i.e., a tightly packed layer of wind and water eroded pebbles) and only support sparse stands of creosotebush, white brittle bush, and white bursage (Ambrosia dumosa Gray). Larger washes have an overstory of ironwood and blue palo verde. The common understory species are cresotebush, wolfberry, globe mallow (Sphaeralcea spp.), and brittle bush (Rautenstrauch et al. 1988).

\section{Diet Studies}

We estimated diets of desert mule deer in each study area by micro-histological identification of plant epidermal fragments in fecal material (Sparks and Malechek 1968, Vavra and Holechek 1980). We collected a fresh composite fecal sample ( $\geq 10$ pellets from $\geq 5$ pellet groups) in the middle of the 4 seasons: winter (Jan.-Mar.); spring (Apr.-Jun.); summer (Jul.-Sep.); and autumn (Oct.-Dec.). Pellets were collected in the Belmont Mountains during January 1980 through December 1981, in the Picacho Mountains during January 1981 through September 1982, and in King Valley during September 1983 through June 1984. Pellet groups were stored in $70 \%$ ethyl alcohol until analyses were performed at the University of Arizona Forage Analysis Laboratory.

After the pellet groups were composited, 5 slides per composite were examined through a compound microscope set at $100 \mathrm{X}$. We randomly selected 20 microscopic fields per slide that contained $\geq 7-10$ identifiable particles. We computed frequencies for each plant species and converted them to particle density (Fracker and Brischle 1944). We obtained relative density by the equation of Sparks and Malechek (1968). The technician responsible for micro-histological identification of plant epidermal fragments in fecal material was experienced and tested to ensure reliability (Krausman et al. 1989). We classified plant species as browse (i.e., perennial shrubs), forb (i.e., annual, herbaceous plants), grass, or succulent (i.e., Agave spp., cactuses, or Yucca spp.). Plant names follow Lehr (1978) and Scott and Wasser (1980).

\section{Literature Review}

We reviewed the literature for quantitave studies of desert mule deer diets in the United States. We excluded references that contained statements of what desert mule deer eat based on general knowledge or casual observations. We included plant species in our summary if $\geq 1$ study reported their contribution to the diet as $\geq 1 \%$ during $\geq 1$ season. Because diet studies differ in a variety of ways including method of data collection, availability of plant species, and number of animals within the study area, we could not compare results in terms of direct numbers. Instead we categorized the quantities recorded into 3 groups: low ( $1-5 \%$ of the diet), medium ( $>5-15 \%$ of the diet), and high use (> $15 \%$ of the diet).

\section{Results}

\section{Diet Studies}

Desert mule deer at the 3 study sites ate a variety of plants (Tables 1-3). In the Belmont Mountains, 29 plant species contributed $\geq 1 \%$ to the diet, followed by the Picacho Mountains ( $n=$ $23)$, and King Valley $(n=14)$. Many plant species in the diet made up $\leq 1 \%$ of the total diet: 29 species at Picacho Mountain, 24 at Belmont Mountain, and 14 at King Valley.

Overall, browse comprised the highest percent of the diet at all study sites (Tables 1-3). Important browse species included desert ironwood (King Valley and Belmont Mountains), jojoba (Picacho and Belmont mountains), janusia (Janusia gracilis Gray), wild buckwheat (Eriogonum spp.) (Picacho Mountains), and smoketree (Dalea spinosa Gray) (King Valley).

Diets varied seasonally at all study sites. Forb consumption increased and browse consumption decreased during winter and spring when forb production was high as a result of winter precipitation. Forb species during these seasons included lupine (Lupinus spp.) and paperflower (Psilotrophe spp.) at Picacho Mountain, filaree (Erodium cicutarium [L.]L'Her.) at King Valley, and pursh plantain (Plantago purshii R. \& S.) in the Belmont Mountains. Combined succulent species comprised $<5 \%$ of the diet at all study sites. Grass also comprised a low percent of the diet at each site. However, Mediterranean grass (Schismus barbatus [L.] Thell.) and Bigelow's blucgrass (Poa bigelovii Vasey \& Scribn.) comprised 5.7\% of the diet in the Belmont Mountains during winter 1980 (Table 1).

\section{Literature Review}

Fourteen studies of desert mule deer diets were found that met our review criteria (Table 4). The methods of data collection for these studies fell into 3 categories: rumen analysis, fecal analysis, and feeding observations of wild deer. Most of the studies provided diet information on a seasonal basis. Because of the variety of ways in which seasons were defined (Table 4), we did not standardize seasons in our summary tables.

Ninety-two browse and 14 succulent plant species constituted $\geq 1 \%$ of the diet of desert mule deer throughout their range in the United States during $\geq 1$ season (Table 5 ). The majority of these species $(79 \%)$ were found in $\leq 2$ studies. Range ratany (Krameria parvifolia Benth.) occurred in 7 studies and use levels varied seasonally from low to high. Jojoba and honey mesquite (Prosopis glandulosa Torr.) both were found in 6 studies. Catclaw (Acacia greggii Gray) occurred in 5 studies conducted in Arizona with levels of use ranging from low during winter and spring to low through high levels during summer and fall. Catclaw also was documented in an additional Arizona study at trace levels $(<1 \%)$. Another common browse species in Arizona is fairy duster (Calliandra eriophylla Benth.), which occurred at low to high levels in 4 studies and in trace amounts in 1 study. Use levels of fairy duster were high during summer and autumn. Other species that occurred in $>3$ studies included true mountain mahogany (Cercocarpus montanus Raf.), wild buckwheat (Eriogonum spp.), Wright's buckwheat (E. Wrightii Torr.), janusia, juniper (Juniperus spp.), shrub live oak (Quercus turbinella Greene), and squaw bush (Rhus trilobata Nutt.)

Prickly pear cactus (Opuntia spp.) was the most common succulent, occurring in 7 studies. Use of this plant by deer was low 
Table 1. Percent relative density of plant species in seasonal diets of desert mule deer in the Belmont Mountains, Arizona as determined by fecal composition analysis, 1980-82.

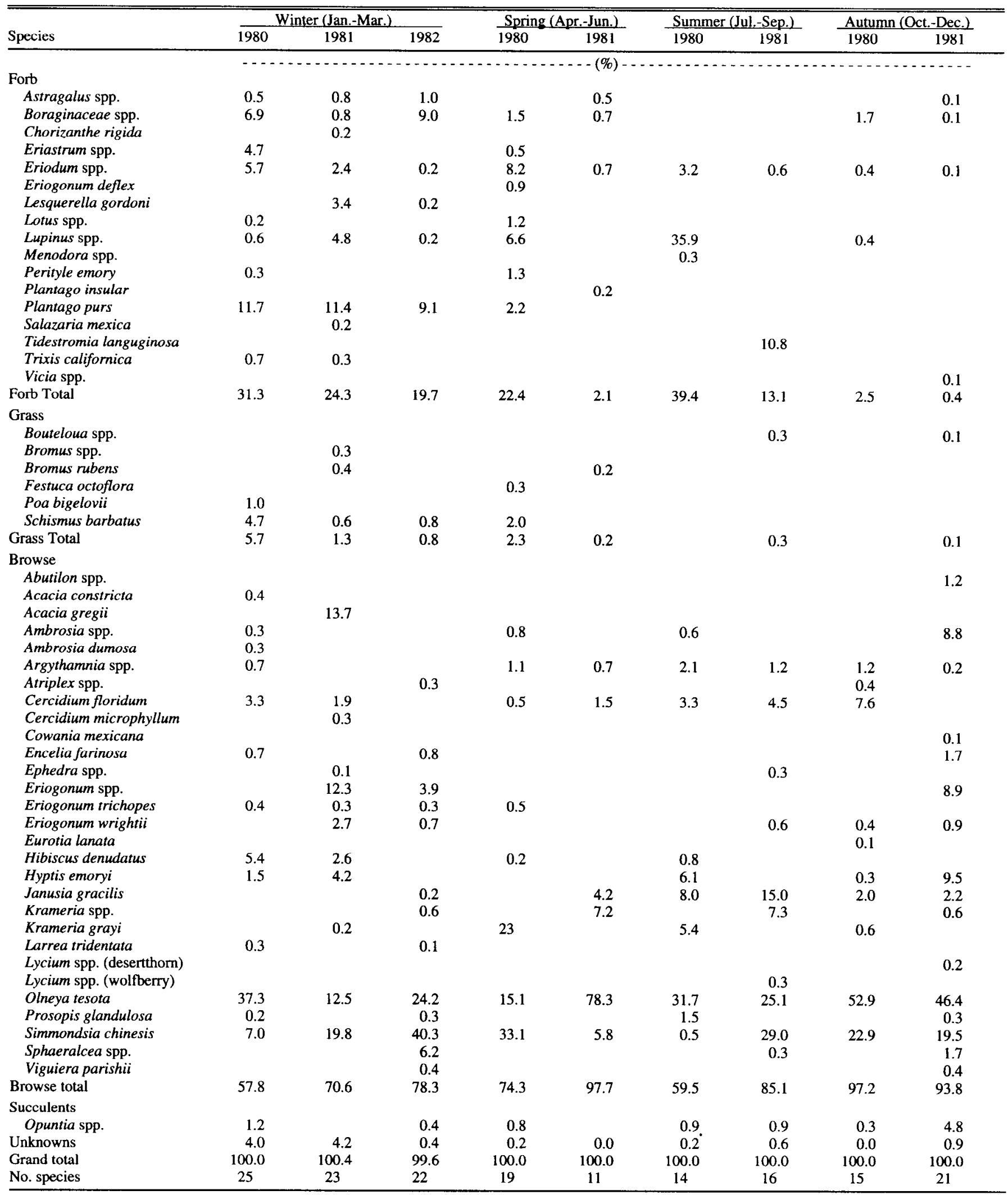


Table 2. Percent relative density of plant species in seasonal diets of desert mule deer in the Picacho Mountains, Arizona as determined by fecal composition analysis, 1981-82.

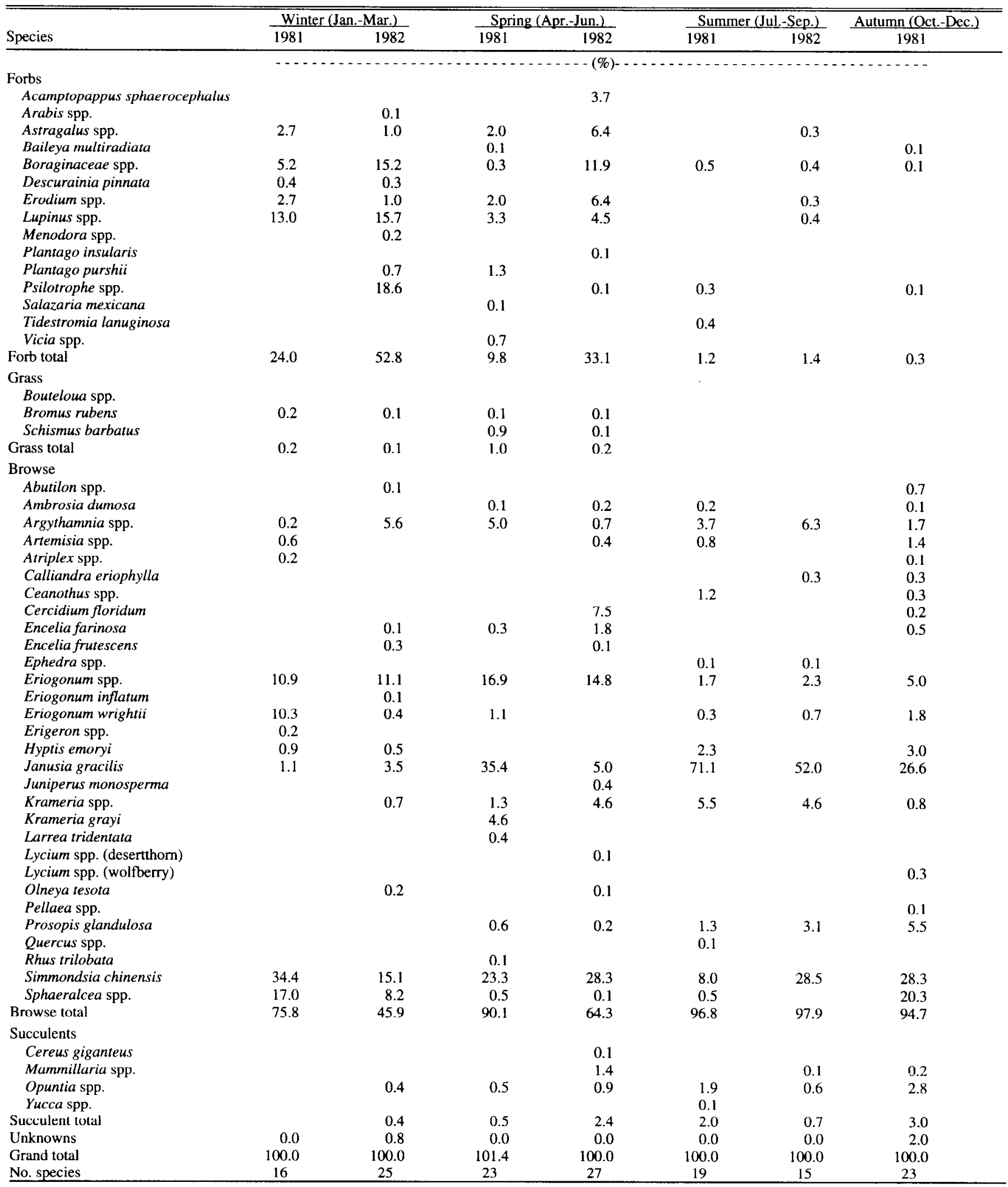


Table 3. Percent relative density of plant species in seasonal diets of desert mule deer in King Valley, Arizona as determined by fecal composition analysis, September 1983-June 1984.

\begin{tabular}{|c|c|c|c|c|}
\hline Species & $\begin{array}{c}\text { Winter } \\
\text { (Jan_-Mar.) }\end{array}$ & $\begin{array}{c}\text { Spring } \\
\text { (Apr.-Jun.) }\end{array}$ & $\begin{array}{c}\text { Summer } \\
\text { (Jul.-Sept.) }\end{array}$ & $\begin{array}{c}\text { Autumn } \\
(\text { Oct.-Dec. })\end{array}$ \\
\hline \multicolumn{5}{|l|}{ Forbs } \\
\hline Astragalus spp. & & & & 0.2 \\
\hline Boraginaceae spp. & 0.6 & 0.1 & 3.0 & 1.2 \\
\hline Erodium cicutarium & 9.7 & 31.1 & 1.5 & 7.7 \\
\hline Euphorbia spp. & 0.1 & & & 0.2 \\
\hline Lotus spp. & 0.2 & & & \\
\hline Plantago insularis & 23.2 & 1.9 & 1.5 & 4.3 \\
\hline Polygala macradenia & & & & 0.1 \\
\hline Salazaria mexicana & 0.1 & & & \\
\hline Sphaeralcea spp. & 0.5 & 0.3 & & 0.4 \\
\hline Tidestromia lanuginosa & 0.4 & & & 0.1 \\
\hline Unknown forb & & 0.1 & & \\
\hline Forb total & 34.8 & 33.5 & 6.0 & 14.2 \\
\hline \multicolumn{5}{|l|}{ Grass } \\
\hline Bouteloua spp. & & 0.1 & & \\
\hline Muhlenbergia spp. & & & 1.5 & \\
\hline Schismus barbatus & 0.1 & 0.2 & 1.5 & 0.4 \\
\hline Unknown grass & & 0.1 & & \\
\hline Grass total & 0.1 & 0.4 & 3.0 & 0.4 \\
\hline \multicolumn{5}{|l|}{ Browse } \\
\hline Ambrosia dumosa & 1.2 & 0.6 & & 0.6 \\
\hline Cercidium spp. & 0.1 & 4.5 & 8.0 & 2.6 \\
\hline Dalea spinosa & 18.9 & 3.2 & 14.0 & 31.5 \\
\hline Encelia farinosa & 0.1 & & & 0.1 \\
\hline Ephedra spp. & 0.1 & & & \\
\hline Eringonum spp. & 1.1 & & & \\
\hline Hyptis emoryi & & 0.3 & & 0.2 \\
\hline Janusia gracilis & & & & 0.1 \\
\hline Krameria parvifolia & 1.6 & 19.4 & 4.5 & 0.4 \\
\hline Olneya tesota & 40.8 & 35.9 & 49.0 & 44.1 \\
\hline Prosopis juliflora & 0.4 & 1.6 & 8.5 & 1.2 \\
\hline Simmondsia chinensis & 0.3 & 0.6 & 3.0 & 3.4 \\
\hline Browse total & 64.6 & 66.1 & 87.0 & 84.2 \\
\hline \multicolumn{5}{|l|}{ Succulents } \\
\hline Opuntia spp. & 0.3 & & 3.0 & 0.9 \\
\hline Unknowns & 0.2 & 0.0 & 1.0 & 0.3 \\
\hline Grand total & 100.0 & 100.0 & 100.0 & 100.0 \\
\hline No. Species & 20 & 16 & 12 & 20 \\
\hline
\end{tabular}

for most seasons, but use was documented at high and medium levels during spring and summer for $\geq 1$ study. Other succulent species eaten by deer in $\geq 2$ studies were Engelmann's prickly pear ( $O$. phaeacantha Engelm.) ( $n=5$ studies) and lecheguilla agave (Agave lecheguilla Torr.), which was found in 3 of the 4 studies conducted in Texas.

Six grass and 69 forb species constituted $\geq 1 \%$ of the diet of desert mule deer during $\geq 1$ season (Table 6). All of the grass species and $91 \%$ of the forb species occurred in $\leq 2$ studies. Forb species documented in $\geq 2$ studies included spurge (Euphorbia. spp.), lupine, fleabane (Eriastrum spp.), menodora (Menodora spp.), filaree, and borage (Boraginaceae spp.). In general, use of these species were higher during winter and spring.

Most species that comprised $\leq 1 \%$ of the diet for all seasons and studies (Table 7) may be of little importance in management considerations; however, they may contain important micronutrients. The role of micronutrients in the diet of desert mule deer needs further study.
Table 4. Summary of the location and type of data collected for desert mule deer diet studies.

\begin{tabular}{llclc}
\hline \hline State & Reference & $\begin{array}{c}\text { Type of } \\
\text { data }^{\mathrm{a}}\end{array}$ & $\begin{array}{l}\text { Seasonal } \\
\text { data }\end{array}$ & $\begin{array}{c}\text { Seasons } \\
\text { defined }^{\mathrm{b}}\end{array}$ \\
\hline Arizona & Anthony (1976) & $\mathrm{F}$ & No & \\
Arizona & Anthony and Smith (1977) & $\mathrm{F}$ & 4 seasons & 1 \\
Arizona & Krausman et al. (1989) & $\mathrm{F}$ & 4 seasons & 2 \\
Arizona & Umess (1981:353) & $\mathrm{R}$ & Winter, spring & 2 \\
Arizona & McCulloch (1973) & $\mathrm{R}$ & 4 seasons & 2 \\
Arizona & Short (1977) & $\mathrm{R}$ & 4 seasons & 3 \\
Arizona & Truett (1971) & $\mathrm{O}$ & 4 seasons & 4 \\
New Mexico & Boeker et al. (1972) & $\mathrm{R}$ & 4 seasons & 5 \\
New Mexico & Anderson et al. (1965) & $\mathrm{R}$ & 4 seasons & 2 \\
New Mexico & Snyder (1961) & $\mathrm{R}$ & No & \\
Texas & Krausman (1978) & $\mathrm{R}$ & 4 seasons & 1 \\
Texas & Leopold and Krausman (1987) & $\mathrm{F}$ & 4 seasons & 1 \\
Texas & Keller (1975) & $\mathrm{R}$ & 4 seasons & 6 \\
Texas & Uzzell (1958) & $\mathrm{R}$ & Winter & 5 \\
\hline
\end{tabular}

${ }^{a} \mathrm{~F}=$ fecal pellet composition, $\mathrm{R}=$ numen contents $\mathrm{O}=$ feeding observations.

${ }^{b} 1$ = winter (Nov.-Jan.), spring (Feb.-Apr.), summer (May-Jul.), late summer/autumn (Aug.-Oct.), 2 = winter (Jan.-Mar.), spring (Apr.-Jun.), summer (Jul.-Sep.), autumn (Oct.-Dec.), 3 = winter (Dec.-Feb.), spring (Apr.-May), summer (Aug.-Sep.), autumn (Oct.-Nov.), $4=1$ Feb. -30 Apr., I May-15 Jul., 16 Jul. -15 Oct. 16 Oct.-31 Jan., $5=$ timing of seasons undefined, $6=$ winter $($ Dec-Feb.), spring (Mar-May), summer (Jun.-Aug.), autumn (Sep.-Nov.).

\section{Discussion and Conclusions}

Diets of desert mule deer varied among the 3 Arizona study sites, seasonally within years, and from year to year. Such variation is not uncommon; other desert mule deer diet studies have found similar patterns (Short 1977, Krausman 1978, Leopold and Krausman 1987). Diet composition likely varies as a result of climatic influence on relative availability and phenology of plant species (Hansen and McCulloch 1955). Anthony (1976) found that drought had an effect on desert mule deer diets in south-central Arizona and Anderson et al. (1965) reported that forbs were the dominant item in diets during wet years with browse dominant during dry years. Our study indicated that browse was the dominant forage consumed by desert mule deer throughout their range in the United States.

Changes in diet composition are likely influenced by changes in nutrient levels. Swank (1956) found that crude protein and phosphorous contents of most browse species in Arizona chaparral varied seasonally, increasing during seasons of active growth. Urness et al. (1971) analyzed seasonal diets of desert mule deer in central Arizona to estimate nutrient intake. They found that although diets varied seasonally, protein and phosphorous intake was constant year round. Browse was found not to supply protein in proportion to its consumption in mid winter and early spring but was equal to or exceeded consumption during the other seasons. Payton and Garner (1980) reported that nutrient levels of forages of desert mule deer in southwest Texas were highest following seasonal rains. This was also the case for forage in the Picacho Mountains and in King Valley. Krausman et al. (1990) and Rautenstrauch et al. (1988) found higher levels of protein in 12 of 19 plants sampled in the Picacho Mountains and 8 of 16 plants sampled in King Valley, during summer monsoons from July to October. 
Table 5. Browse and succulents reported as food of desert mule deer.

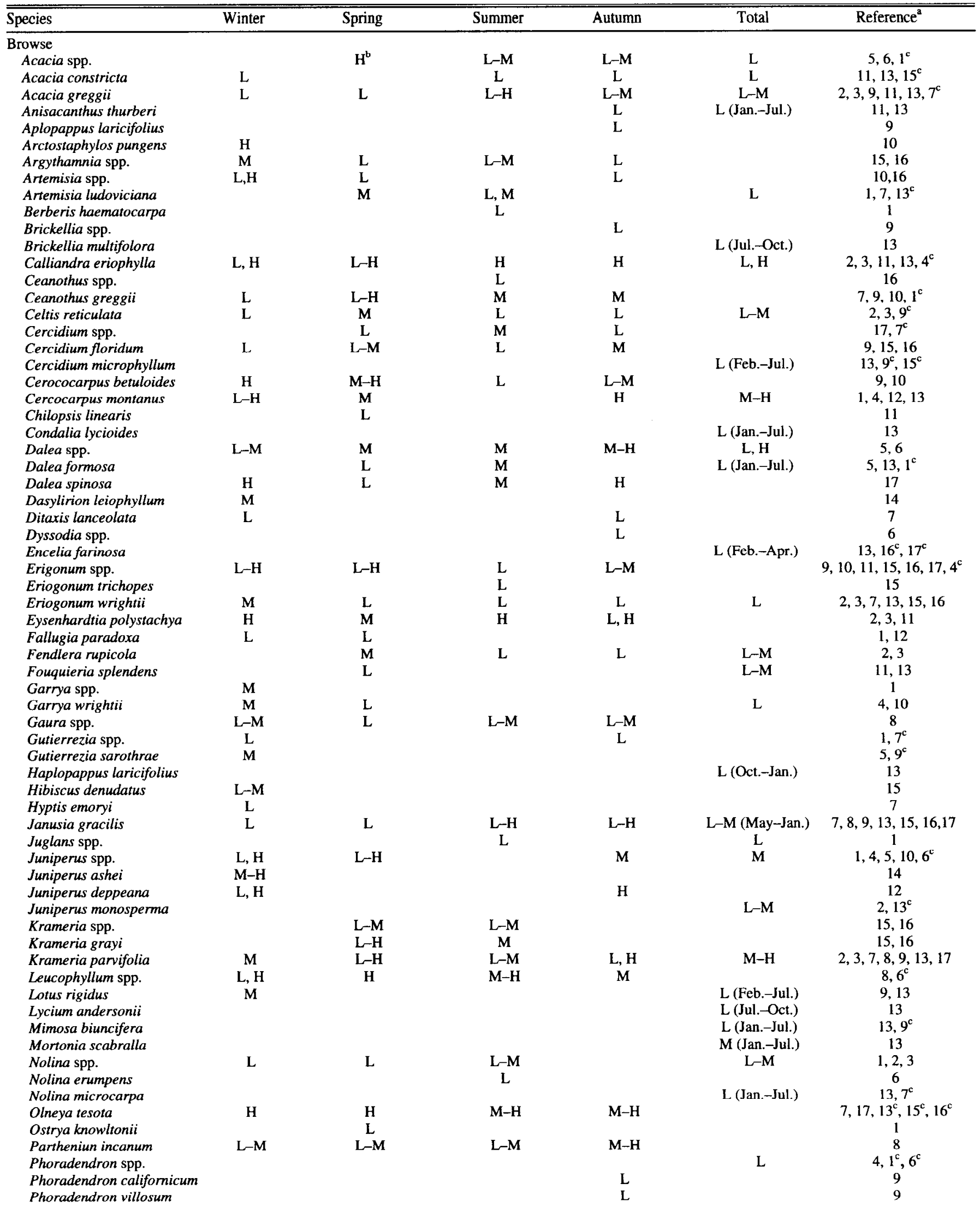


Table 5. (Continued)

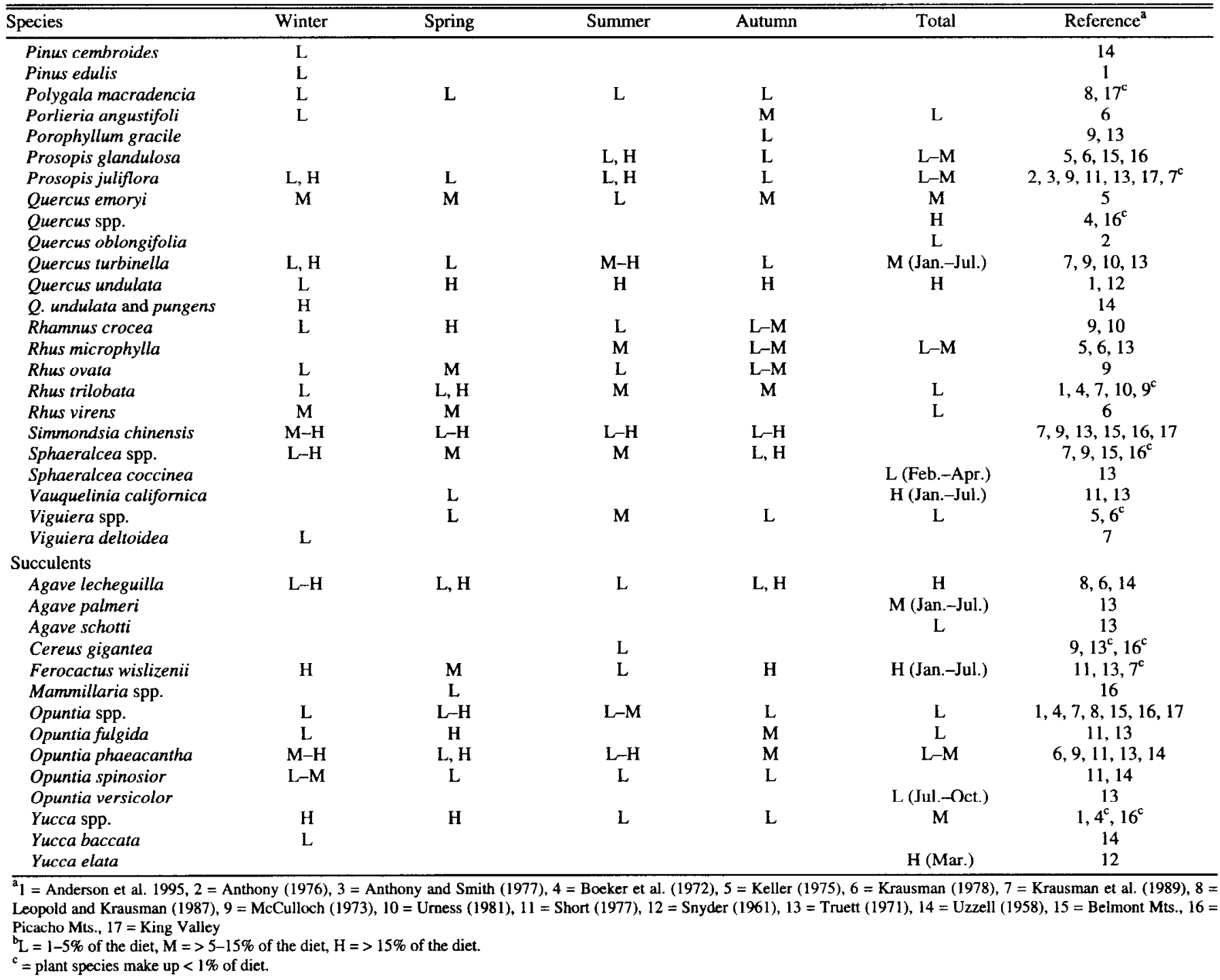

Table 6. Forbs and grass reported as food for the desert mule deer.

\begin{tabular}{|c|c|c|c|c|c|c|}
\hline Species & Winter & Spring & Summer & Autumn & Total & ReferenceForbs \\
\hline \multicolumn{7}{|l|}{ Forbs } \\
\hline Abutilon spp. & $\mathbf{M}^{\mathrm{b}}$ & $\mathbf{L}$ & L & $\mathbf{L}-\mathbf{M}$ & & 8,9 \\
\hline Acamptpappus sphaerocephalus & & $\mathbf{L}$ & & & & 16 \\
\hline Allium spp. & & $\mathrm{L}$ & & & & 5 \\
\hline Ambrosia confertiflora & L & & & $\mathrm{L}$ & & $9,13^{\mathrm{c}}$ \\
\hline Anemone tuberosa & $\mathrm{L}$ & & & & & 9 \\
\hline Anisacanthus thurberi & & & & & L-M & 2 \\
\hline Astragalus spp. & $\mathrm{L}$ & $\mathbf{L}-\mathbf{M}$ & & & & $15,16,17^{\mathrm{c}}, 4^{\mathrm{c}}, 7^{\mathrm{c}}$ \\
\hline Baileya multiradiata & & $\mathrm{L}$ & & & M (Jan.-Jul.) & $11,13,7^{\mathrm{c}}, 16^{\mathrm{c}}$ \\
\hline Boraginaceae & $\mathbf{M}$ & $\mathbf{M}$ & L & $\mathrm{L}$ & & $15,16,17$ \\
\hline Calochortus kennedyi & & $\mathbf{L}$ & & & & 9 \\
\hline Carlowrightia arizonica & & & & & L (Jul.-Jan.) & 13 \\
\hline Commelina dianthifolia & & & & & $\mathrm{L}$ & 4 \\
\hline Compositae & $\mathrm{L}$ & & & $\mathrm{L}$ & & 9 \\
\hline
\end{tabular}

(Continued on page 520) 
Table 6. (Continued)

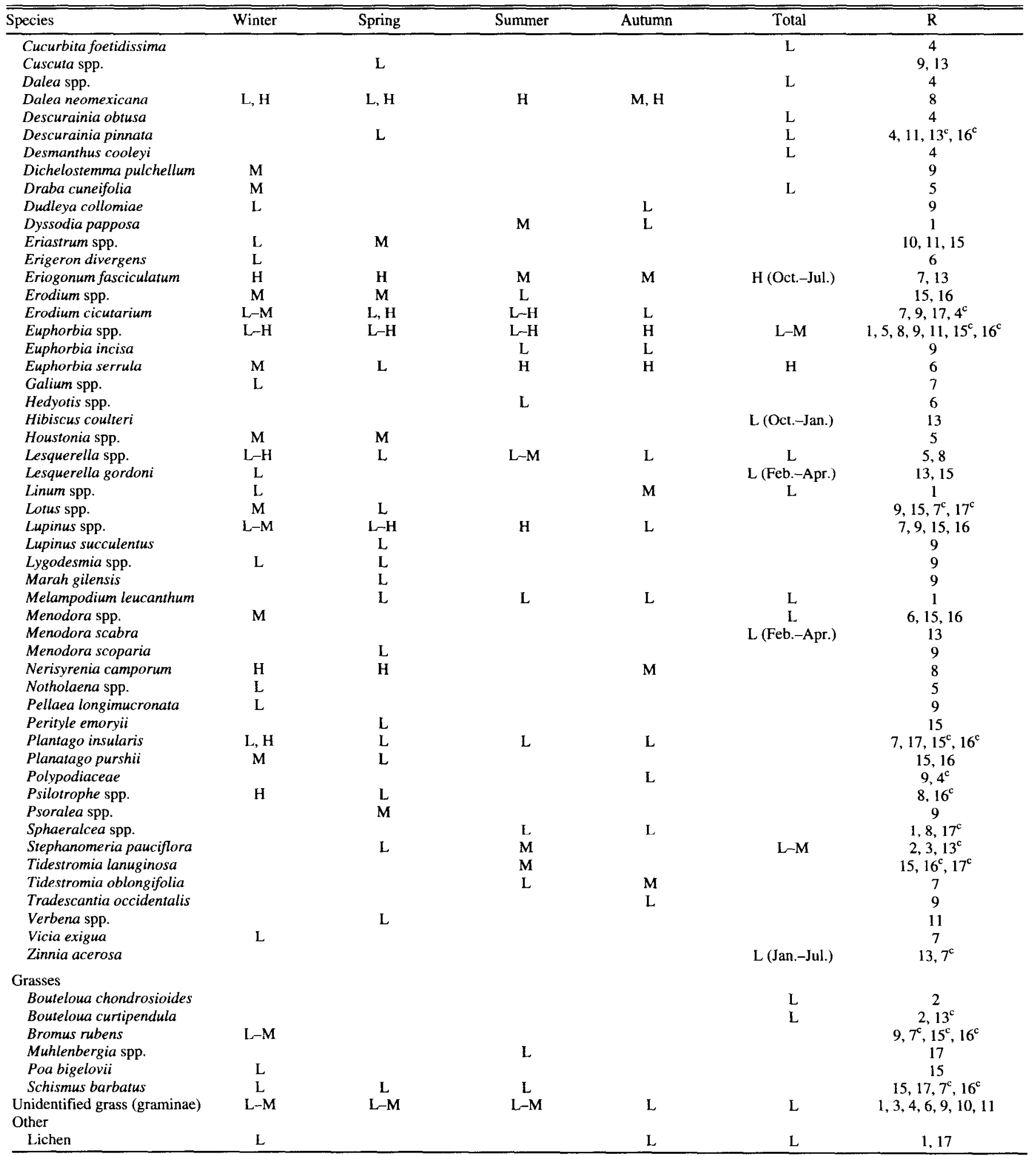

${ }^{a} 1=$ Anderson et al. (1995), $2=$ Anthony (1976), $3=$ Anthony and Smith (1977), $4=$ Boeker et al. (1972) $5=$ Keller (1975), $6=$ Krausman (1978), $7=$ Krausman et al. (1989), $8=$ Leopold and Krausman (1987), 9 = McCulloch (1973), $10=$ Urmess (1981), $11=$ Short (1977), 12 = Snyder (1961), $13=$ Truett $(1971), 14=$ Uzzell (1958), $15=$ Belmont Mts., $16=$ Picacho Mts., $17=$ King Valley.

$\mathrm{b}_{\mathrm{L}}=1-5 \%$ of the diet, $\mathrm{M}=>5-15 \%$ of the diet, $\mathrm{H}=>15 \%$ of the diet.

${ }^{c}=$ plant species make up $<1 \%$ of diet. 
Table 7. Plant species reported as foods of desert mule deer in trace amounts $(<1 \%)$.

\begin{tabular}{|c|c|}
\hline Species & References $^{\mathrm{a}}$ \\
\hline \multicolumn{2}{|l|}{ Browse } \\
\hline Ambrosia deltoidea & 7 \\
\hline Ambrosia dumosa & $7,15,16,17$ \\
\hline Amborsia spp. & 15 \\
\hline Amelanchier spp. & 1 \\
\hline Arbutus texana & 1 \\
\hline Artemesia carruthii & 1 \\
\hline Atriplex spp. & $7,15,16$ \\
\hline Atriplex canescens & 1 \\
\hline Cowania mexicana & 15 \\
\hline Clematis spp. & 1 \\
\hline Diospyros texana & 6 \\
\hline Dyssodia porophylloides & 13 \\
\hline Ephedra spp. & $7,15,16,17$ \\
\hline Erigeron spp. & 13,16 \\
\hline Eriogonum inflatum & 7,16 \\
\hline Eurotia lanata & 15 \\
\hline Forestiera angustifolia & 6 \\
\hline Haplopappus gracilis & 13 \\
\hline Hoffmanseggia spp. & 6 \\
\hline Larrea tridentata & 15,16 \\
\hline Lycium spp. (wolfberry) & 15,16 \\
\hline Lycium spp. (desert thom) & 15,16 \\
\hline Lycium exsertum & 9 \\
\hline Mimosa dysocarpa & 2 \\
\hline Pellaea spp. & 16 \\
\hline Phoradendron juniperinum & 1 \\
\hline Prosopis spp. & 1 \\
\hline Prosopis havardii & 6 \\
\hline Ptelea trifoliata & 1 \\
\hline Rhus choriophylla & 13 \\
\hline Solanum xanti & 9 \\
\hline Symphoricarpos spp. & 1 \\
\hline Viguiera parishii & 15 \\
\hline Xanthocephalum spp. & 6 \\
\hline \multicolumn{2}{|l|}{$\begin{array}{l}\text { Succulents } \\
\text { Sulum spp. }\end{array}$} \\
\hline Agave spp. & 1,7 \\
\hline Echinocereus spp. & 13 \\
\hline \multicolumn{2}{|l|}{ Forbs } \\
\hline Amaranthus fimbriatus & 13 \\
\hline Amsinkia spp. & 13 \\
\hline Arabis spp. & 16 \\
\hline Argemone platyceras & 2 \\
\hline Bahia spp. & 6 \\
\hline Boerhaavia intermedia & 13 \\
\hline Chenopodiem spp. & 1 \\
\hline Chenopodium album & 4 \\
\hline Chorizanthe spp. & 1 \\
\hline Chorizanthe rigida & 7,15 \\
\hline Crassulaceae (spp.) & 1 \\
\hline Cruciferae (spp.) & 1 \\
\hline Eriogonum deflexum & 15 \\
\hline Friogonum harardii & 1 \\
\hline Euphorbia polycarpa & 13 \\
\hline Evolvulus arizonicus & 13 \\
\hline Gilia spp. & 4 \\
\hline Hedeoma costata & 1 \\
\hline Kallstroemia grandiflora & 13 \\
\hline Lepidium spp. & 13 \\
\hline Lesquerella fendleri & 1 \\
\hline Liliaceae (spp.) & 1 \\
\hline Margaranthus solanaceus & 9 \\
\hline Melilotus albus & 4 \\
\hline Mirabilis spp. & 7 \\
\hline Mirabilis bigelovii & 7,13 \\
\hline Mirabilis multiflora & 4 \\
\hline Physalis fendleri & 4 \\
\hline Plantago spp. & 9 \\
\hline Pseudocymopterus montanus & 9 \\
\hline
\end{tabular}

Table 7. (Continued).

\begin{tabular}{lc}
\hline \hline Species & References $^{\mathrm{a}}$ \\
\hline Psilotrophe cooperi & 7 \\
Salazaria mexicana & $7,16,17$ \\
Salsola kali & 1 \\
Sisymbrium irio & 13 \\
Stenandrium barbatum & 1 \\
Teucrium spp. & 1 \\
Thlaspi spp. & 1 \\
Trifolium spp. & 7,15 \\
Trixis californica & 1 \\
Verbena wrightii & 15,16 \\
Vicia spp. & 1 \\
Viguiera spp. & 9 \\
Grass & 13 \\
Bouteloua spp. & 13 \\
Bouteloua eriopoda & 15 \\
Bouteloua filiformis & 15 \\
Bromus spp. & 9 \\
Festuca octoflora & 7 \\
Hilaria belangeri & 7 \\
Hilaria rigida & 9 \\
Muhlenbergia porteri & 7 \\
Poa spp. & Tridens pulchellus
\end{tabular}

${ }^{a} 1=$ Anderson et al.(1995), $2=$ Anthony (1976), $3=$ Anthony and Smith (1977), $4=$ Boeker et al. (1972) $5=$ Keller (1975), $6=$ Krausman (1978), $7=$ Krausman et al. (1989), $8=$ Leopold and Krausman (1987), $9=$ McCulloch (1973), $10=$ Urness (1981), 11 = Short (1977), 12 = Snyder (1961) 13 = Truett (1971), $14=$ Uzzell (1958), $15=$ Belmont Mts., $16=$ Picacho Mts., 17 = King Valley.

Desert mule deer eat a wide variety of plant species across their range. Browse (range $=45.9-97.9 \%$ ) is consumed more than the other forage classes and when combined with forbs makes up $>93 \%$ of the overall diet of desert mule deer. Grasses and succulents make up $<1 \%$ of the diet in $50 \%$ of the seasons sampled and never exceeded $7 \%$ of the diet in the other seasons (range $=1.2-6.9 \%$ ). It is difficult to generalize about the importance of individual plant species within their diet, because diet composition varies spatially and temporally.

\section{Management Implications}

Because rainfall is not predictable in deserts, the ability of desert mule deer to consume a wide variety of browse (126 species) and forbs (111 species) (Tables 5,7) allows them to take advantage of plant availability and those with higher nutritive value. Overall, the vegetation diversity provides ample choices for mule deer to be highly opportunistic feeders. Variability in available forage is a result of unpredictable rains, drought, and other climatic factors (Peek and Krausman 1996). Succulents may play an important rolc during drought and may be under represented in the studies presented here. They have high ( $>90 \%$ ) moisture content and may not be adequately represented in micro-histological or rumen analysis. The range manager cannot anticipate the weather. However, the implications are obviously to keep desert rangelands productive with a diversity of forage so animals have opportunities to exercise free choice of diet.

\section{Literature Cited}

Anderson, A.E., W.A. Snyder, and G.W. Brown. 1965. Stomach content analyses related to condition in mule deer, Guadalupe Mountains, New Mexico. J. Wildl. Manage. 29:352-366. 
Anthony, R.G. 1976. Influence of drought on diets and numbers of desert deer. J. Wildl. Manage. 40:140-144.

Anthony, R.G. and N.S. Smith. 1977. Ecological relationships between mule deer and while-tailed deer in southeastern Arizona. Ecol. Monog. 47:255-277.

Boeker, E.L., V.E. Scott, H.G. Reynolds, and B.A. Donaldson. 1972. Seasonal food habits of mule deer in southwestern New Mexico. J. Wildl. Manage. 36:56-63.

Fracker, S.B. and H.A. Brischle. 1944. Measuring the local distribution of ribes. Ecol. 25:283-303.

Hansen, W.R. and C.Y. McCulloch. 1955. Factors influencing mule deer on Arizona brushlands. Trans. North. Amer. Wildl. Conf. 20:568-588.

Hoffmeister, D.F. 1962. The kinds of deer, Odocoileus, in Arizona Amer. Midl. Nat. 67:45-64.

Keller, G.L. 1975. Seasonal food habits of desert mule deer (Odocoileus hemionus crooki) on a specific mule deer-cattle range in Pecos County, Texas. M.S. Thesis, Sul Ross State Univ., Alpine, Tex. 80 pp.

Krausman, P.R. 1978. Forage relationships between two deer species in Big Bend National Park, Texas. J. Wildl. Manage. 42:101-107.

Krausman, P.R., L.L. Ordway, F.M. Whiting, and W.H. Brown. 1990. Nutritional composition of desert mule deer forage in the Picacho Mountains, Arizona. Desert Plants 10:32-34.

Krausman, P.R., B.D. Leopold, R.F. Seegmiller, and S.G. Torres. 1989. Relationships between desert bighorn sheep and habitat in west ern Arizona. Wildl. Monogr. 102:66 pp.

Lehr, J.H. 1978. A catalogue of the flora of Arizona. Northland Press, Flagstaff, Ariz. 203 pp.

Leopold, B.D. and P.R. Krausman. 1987. Diets of two desert mule deer herds in Big Bend National Park, Texas. Southwest. Nat. 323:449-455.

Litvaitis, J.A., K.Titus, and E.M. Anderson. 1994. Measuring vertebrate prey use of terrestrial habitats and foods, p 254-274. In: T.A. Bookhout, (ed), Research and management techniques for wildlife and habitats. Fifth ed. The Wildlife Society, Bethesda, Md.

McCulloch, C.V. 1973. Seasonal diets of mule and white-tailed deer, $p$. 1-3.7 In: Deer nutrition Arizona chaparral and desert habitats. Arizona Game and Fish Dept., Phoenix, Ariz. Spec. Rep. 3.

Payton, T.W. and G.W. Garner. 1980. Nutritional values for selected forages of desert mule deer in southwest Texas. Proc. Ann. Conf. Western Assoc. Fish Wildl. Agencies 60:601-619.
Peek, J.M. and P.R. Krausman. 1996. Grazing and mule deer, p. 183-192. In: P.R. Krausman, (ed.).Rangeland wildlife. Soc. Range. Manage., Denver, Colo.

Rautenstrauch, K.R., P.R. Krausman, F.W. Whiting, and W.H. Brown. 1988. Nutritional quality of desert mule deer forage in King Valley, Arizona. Desert Plants 8:172-174.

Scott, T.G. and C.H. Wasser. 1980. Checklist of North American plants for wildlife biologists. The Wildlife Soc., Washington, D.C. 58 pp.

Sellers, W.D. and R.H. Hill, editors. 1974. Arizona climate: 1931-1972. Univ. Arizona Press, Tucson, Ariz. 616 pp.

Short, H.L. 1977. Food habits of mule deer in a semi-desert grass-shrub habitat. J. Range Manage. 30:206-209.

Snyder, W.A. 1961. A chemical analysis of thirteen major deer forage plants from the Guadalupe Mountains of New Mexico and their adequacy for maintaining deer. MS thesis. New Mexico State Univ., Las Cruces, N.M.

Sparks, D.K. and J.C. Malechek. 1968. Estimating percentage dry weight in diets using a microscopic technique. J. Range Manage. 21:264-265.

Swank, W.G. 1956. Protein and phosphorus content of browse plants as an influence on southwestern deer herd levels. Trans. North Amer. Wildl. Conf. 21:141-158.

Truett, J.C. 1971. Ecology of the desert mule deer, Odocoileus hemionus crooki Mearns, in Southeastern Arizona. Ph.D. Diss. Univ Arizona, Tucson, Ariz.

Uzzell, P.B. 1958. Deer food habits study: Trans-Pecos game management survey. P-R Project W-57-R Job 7. Texas Game and Fish Comm., Austin, Tex. 21 pp.

Urness, P.J., W. Green, and R.K. Watkins. 1971. Nutrient intake of deer in Arizona chaparral and desert habitats. J. Wildl. Manage. $35: 469-475$.

Urness, P.J. 1981. Desert and chaparral habitats, p.347-385. In: O.C. Wallmo, (ed). Mule and black tailed deer of North America. Univ. Nebraska Press, Lincoln, Neb.

Vavra, M. and J.L. Holechek. 1980. Factors influencing micro-histological analysis of herbivore diets. J. Range Manage. 33:371-374.

Wallmo, O.C. 1981. Mule and black-tailed deer distribution and habitats, p. 1-26. In: O.C. Wallmo, (ed.) Deer of North America. Univ. Nebraska Press, Lincoln, Neb. 